\title{
Role of glucose in enhancing life and potency of Cirrhinus mrigala spermatozoa during cryopreservation
}

\author{
C. Judith Betsy, J. Stephen Sampath Kumar* and C. B. T. Rajagopalasamy \\ Department of Aquaculture, Fisheries College \& Research Institute, Tuticorin- 628 008, INDIA \\ *Corresponding author. E-mail: jstephenkumar@gmail.com
}

Received: September 13, 2014; Revised received: February 15, 2015; Accepted: March 24, 2015

\begin{abstract}
Cryopreservation of fish gametes is an emerging technology and breeding with cryopreserved gametes is advancement in fish seed production. Success of cryopreservation is evaluated by the post - thaw motility of the spermatozoa, an for which energy is required. Cryopreservation is known to cause changes in the seminal plasma that would alter the energy supply for the motility of the spermatozoa. Therefore, energy supplementation is found to be useful during cryopreservation. Cirrhinus mrigala spermatozoa were cryopreserved along with glucose as a co-cryoprotectant after 1:100 dilutions with $0.85 \%$ physiological saline as extender and Dimethyl Sulfoxide (DMSO) as cryoprotectant (85:15). The diluents contained glucose at four different concentrations, viz., $T_{1}(0.25 \%), T_{2}(0.5 \%), T_{3}(0.75 \%)$ and $\mathrm{T}_{4}(1 \%)$. The diluted milt was equilibrated for $10 \mathrm{~min}$ at $5^{\circ} \mathrm{C}$ and loaded into $0.25 \mathrm{ml}$ straws. The loaded straws were then frozen with $\mathrm{LN}_{2}$ vapour for $5 \mathrm{~min}$ and immersed in liquid nitrogen. Observations were made once in 7 days for 42 days on motility parameters based on which the duration, score, pattern and percentage were determined. The spermatozoa cryopreserved with glucose at $0.5 \%$ concentration showed the highest motility duration of $204 \pm 3.6 \mathrm{~s}$ whereas Control group showed motility duration of only $83.33 \pm 4.5 \mathrm{~s}$ on $42^{\text {nd }}$ day. The difference in motility duration was statistically significant $(P>0.025)$. The present study revealed the benefits of adding glucose at $0.5 \%$ during cryopreservation as it could help in maintaining the motility duration and survival of spermatozoa.
\end{abstract}

Keywords: Cirrhinus mrigala, Cryopreservation, Energy supplements, Glucose, Spermatological parameters

\section{INTRODUCTION}

World aquaculture production during the year 2012 was 90.43 million tonnes and the production of food fish has increased from 59.9 million tonnes in 2010 to 66.63 million tonnes in 2012 (FAO, 2014). It is worth mentioning that $9.41 \mathrm{~kg}$ of food fish per person in the world for consumption has been supplied by aquaculture (FAO, 2014). This shows the potential of aquaculture as a possible enterprise to provide food security for the future generations.

Carps are preferred worldwide for their potential culture qualities and marketability. India is known as a "Carp Country" where among other fishes; Indian major carps contribute significantly for the fish production in the country. C. mrigala has been one of the principle cultured species in India. Being an omnivore and tolerant to different water quality conditions, it has been considered as a good candidate species for aquaculture in India. It is a monsoon breeder having peak breeding during October to December due to copious river flow and nutrient loading due to surface run off.

Breeding of $C$. mrigala is severely influenced by the monsoon failure and hence there is a need for a technology which must ensure seed production throughout the year. Cryopreservation of gametes can help in solving this problem.

Reports on the success of cryopreservation of fish spermatozoa have been made on different fishes (Blaxter, 1953; Henderson and Dewar, 1959; Withler and Morley, 1968; Stein, 1975; Kurokura et al., 1984; Glogowski et al., 1999; Akcay and Bozkurt, 2004; Mohanraj, 2009; Betsy, 2013). Motility is considered as the major factor determining the quality of the spermatozoa (Billard et al., 1995; Lahnsteiner and Patzner, 1998). Since motile spermatozoa can effectively aid in the fertilization of the eggs, it is necessary to retain the motility as maximum as possible in order to have the successful fertilization. Energy will be spent for the flagella movement, and therefore spermatozoa cease swimming when the cellular reserves of energy are exhausted (Christen et al., 1987; Perchec et al., 1995). Hence, supplementing energy is considered as a possibility to encourage the motility of spermatozoa even after cryopreservation.

It has been shown that fish spermatozoa are capable of using exogenous energy sources to a limited extent (Mounib, 1967; Harvey and Kelley, 1984). One of the energy sources studied is glucose which is a non-permeating co-cryoprotectant.

Glucose is the chief substance utilized for energy in the fish semen (Hamner and Charles, 1969). Glucose is used as an external cryoprotectant (Purdy, 2006) and as a 
non-ionic immobilizer in freshwater fish (Horváth et al., 2003; Cruz-Casallas et al., 2004; Viveiros and Godinho, 2009).

Stoss and Refstei (1983) found a very simple extender consisting of $0.3 \mathrm{M}$ glucose and $10 \%$ DMSO to be the most successful of a number of extenders in cryopreservation of the sperm of Atlantic salmon and sea trout which might support the concept of glucose supporting the spermatozoa. Longer motility in the spermatozoa of guppy was noticed when extracellular glucose was given (Gardiner, 1978). Similarly addition of glucose to the extender had enhanced the quality of milt and the storage duration (Ponniah et al., 1999). In Xiphophorus helleri, the addition of glucose yielded higher and longer motility duration for fresh and cryopreserved sperm while the concentration was kept lesser than $11.0 \mathrm{mM}$. The effect was not seen when the concentration of glucose was higher than $11.0 \mathrm{mM}$ (Dong et al., 2006).

Similar application of glucose in the cryopreservation of fish gametes is seen with other fishes too. Bozkurt et al. (2005) reported use of glucose at $300 \mathrm{mM}$ during cryopreservation of rainbow trout spermatozoa. The toxicity of cryoprotectant is reduced by the addition of glucose (Melo and Godinho, 2006). Grace (2013) stated that when monosaccharide glucose was added to the cryoprotectant, the post-thaw survival rate of Arius arius spermatozoa was increased due to the energy supplying nature of glucose. Therefore, the present study aims at identifying the optimal concentration of glucose in the diluents for the cryopreservation of fish milt and its influence on the spermatological parameters like percentage of motile spermatozoa, motility duration, motility score and motility pattern.

\section{MATERIALS AND METHODS}

Adult Cirrhinus mrigala males with average body weight of $1400 \pm 300 \mathrm{~g}$ were collected after checking their maturity. Milt was collected from 3 males as prescribed by Lubzens et al. (1997). The genital pore area was cleaned with double ply tissue paper to remove moisture and mucus and gentle pressure was applied in the abdomen to collect the oozing milt. The milt was collected in a labeled cryovial $(1.5 \mathrm{ml}$ cap). Milt oozing out during the first three to four stripping alone was collected. The vials were kept in the icebox cooled with gel ice at 6 to $10^{\circ} \mathrm{C}$ and then transferred to cold handling chamber (Gilgal Instruments, Bangalore) which was maintained at $5^{\circ} \mathrm{C}$ for further processing. The spermatological parameters of the milt collected were recorded prior to processing.

The collected milt was pooled together and the milt was diluted to 100 folds with $0.85 \%$ physiological saline solution and DMSO (85:15).The total volume of milt collected was $1.5 \mathrm{ml}$ which was divided into 5 portions and glucose were added $(\mathrm{w} / \mathrm{v})$ at 4 different concentrations viz, $\mathrm{T}_{1}(0.25 \%), \mathrm{T}_{2}(0.5 \%), \mathrm{T}_{3}(0.75 \%)$ and $\mathrm{T}_{4}(1 \%)$ and a Control (C) was maintained. The diluted milt was equilibrated for $10 \mathrm{~min}$ at $5^{\circ} \mathrm{C}$ in cold handling chamber (Chao et al., 1987; Sarder et al., 2009).

The equilibrated milt was loaded into $0.25 \mathrm{ml}$ plastic straws and sealed with a polymer powder (IMV, France). Rapid freezing of straws was done for 5 minutes (Leung and Jamieson, 1991) by freezing straws in $\mathrm{LN}_{2}$ vapour. The distance between the straws and $\mathrm{LN}_{2}$ was maintained at $5 \mathrm{~cm}$. They were then transferred to BA11 cryocans containing $\mathrm{LN}_{2}$. Observations were made once in 7 days for 42 days. Ten straws from each treatment were taken at each sampling and thawed at $30^{\circ} \mathrm{C}$ for $30 \mathrm{~s}$ in serological water bath. The thawed milt was observed for the spermatological parameters like motility duration, motility pattern, motility score and percentage of live and dead cells.

The collected milt was observed using NIKON E360 microscope under phase contrast at X 200 magnification. The initial spermatological parameters such as sperm density, motility duration and percentage of live and dead cells were observed and recorded. Suitable motility scores were assigned based on the observation following Guest et al. (1976). Motility duration was evaluated under microscope by placing $1 \mu 1$ of diluted milt sample and $1 \mu 1$ of tap water on a grease free glass slide and estimated as described by Babiak et al. (1995) and the duration were determined in seconds using stopwatch. Motility pattern was classified into forward movement $(+++)$, circular movement $(++)$ and vibratory movement $(+)$ as per the descriptions of Nomura (1964). Percentage of live and dead cells was estimated using Eosin-Nigrosin stain as described by Fribourgh (1966) and Chutia et al. (1998). The data were statistically analyzed by paired t test.

\section{RESULTS}

The mean initial motility duration of the spermatozoa of $C$. mrigala was $230.66 \pm 7.5 \mathrm{~s}$. There was a decrease in the motility duration when observed on $7^{\text {th }}$ day after which the duration increased slowly. The increase in motility duration remained constant on $42^{\text {nd }}$ day. Spermatozoa cryopreserved with glucose at $0.5 \%$ had the highest motility duration of $204 \pm 3.6 \mathrm{~s}$, whereas, that of glucose at $0.75 \%$ had the lowest motility duration of $121 \pm 2.0 \mathrm{~s}$ on $42^{\text {nd }}$ day. Spermatozoa in the Control had motility duration of $83.33 \pm 4.5 \mathrm{~s}$ on $42^{\text {nd }}$ day. All the samples cryopreserved with glucose at different concentrations had relatively higher percentage of motility duration than Control (Table 1). The values observed with the spermatozoa cryopreserved with glucose at $0.5 \%$ concentration was statistically significant $(\mathrm{P}>0.025)$ when compared with Control.

When the motility score is assigned for the observation, it is understood that spermatozoa of all treatments including the Control had a sharp reduction in the motility score after $14^{\text {th }}$ day. It came down to 1 on $42^{\text {nd }}$ day for the Control but the samples contained glucose at different concentrations remained at 2 on $42^{\text {nd }}$ day vouching the fact that the glucose could support the motility better 
Table 1. Mean values of motility duration (s) observed at regular intervals with C. mrigala spermatozoa diluted and cryopreserved with glucose at different concentrations.

\begin{tabular}{|c|c|c|c|c|c|c|c|c|}
\hline \multirow[t]{2}{*}{ Treatment } & \multicolumn{7}{|c|}{ Days of cryopreservation } & \multirow{2}{*}{$\begin{array}{l}\text { Mean } \\
\text { values }\end{array}$} \\
\hline & $\mathbf{0}$ & 7 & 14 & 21 & 28 & 35 & 42 & \\
\hline Glucose $0.25 \%$ & $230.66 \pm$ & $174 \pm$ & $102 \pm$ & $108.33 \pm$ & $122.33 \pm$ & $128.66 \pm$ & $122.33 \pm$ & 141.18 \\
\hline$\left(\mathrm{TG}_{1}\right)$ & 7.5 & 2.6 & 5.5 & 3.1 & 3.0 & 6.0 & 3.0 & \\
\hline Glucose $0.5 \%$ & $230.66 \pm$ & $159.66 \pm$ & $180.33 \pm$ & $182.33 \pm$ & $183 \pm 3.4$ & $183.33 \pm$ & $204 \pm$ & $189.04 *$ \\
\hline$\left(\mathrm{TG}_{2}\right)$ & 7.5 & 2.5 & 7.1 & 10.1 & & 9.2 & 3.6 & \\
\hline Glucose $0.75 \%$ & $230.66 \pm$ & $159 \pm$ & $109 \pm$ & $111.33 \pm$ & $117 \pm$ & $117.33 \pm$ & $121 \pm$ & 137.90 \\
\hline$\left(\mathrm{TG}_{3}\right)$ & 7.5 & 4.0 & 4.5 & 2.5 & 2.0 & 2.1 & 2.0 & \\
\hline Glucose $1 \%$ & $230.66 \pm$ & $151.33 \pm$ & $123.33 \pm$ & $135.66 \pm$ & $159.66 \pm$ & $175.33 \pm$ & $165.66 \pm$ & 163.09 \\
\hline$\left(\mathrm{TG}_{4}\right)$ & 7.5 & 3.0 & 2.5 & 2.5 & 3.0 & 3.5 & 3.1 & \\
\hline Control & $230.66 \pm$ & $167 \pm$ & $103.66 \pm$ & $102.66 \pm$ & $91.33 \pm$ & $90.33 \pm$ & $83.33 \pm$ & 124.13 \\
\hline & 7.5 & 6.5 & 6.0 & 6.0 & 1.5 & 1.5 & 4.5 & \\
\hline
\end{tabular}

Level of significance $*(\mathrm{P}>0.025)$

Table 2. Mean values of motility score observed at regular intervals in C. mrigala spermatozoa cryopreserved with glucose at different concentrations.

\begin{tabular}{lccccccc}
\hline Treatment & \multicolumn{7}{c}{ Days of cryopreservation } \\
\cline { 2 - 7 } & Initial & $\mathbf{7}$ & $\mathbf{1 4}$ & $\mathbf{2 1}$ & $\mathbf{2 8}$ & $\mathbf{3 5}$ & 42 \\
\hline Control & 5 & 4 & 4 & 3 & 2 & 2 & 1 \\
Glucose $0.25 \%$ & 5 & 4 & 3 & 3 & 3 & 3 & 2 \\
Glucose $0.5 \%$ & 5 & 4 & 4 & 4 & 3 & 3 & 2 \\
Glucose $0.75 \%$ & 5 & 4 & 4 & 4 & 3 & 3 & 2 \\
Glucose $1 \%$ & 5 & 4 & 4 & 4 & 3 & 3 \\
\hline
\end{tabular}

(Table 2 and Fig. 1).

The observations on the motility pattern also indicated that the spermatozoa cryopreserved with glucose at $0.25 \%$ and $0.5 \%$ had been uniform with forward movement (Table 3). The percentage of live cells was $71 \%$ in the samples cryopreserved with glucose at $0.5 \%$ (Fig. 2) whereas it was lower for control (63\%). Samples containing glucose at $0.75 \%$ and $1 \%$ concentrations had $64 \%$ and $63 \%$ of live cells respectively on $42^{\text {nd }}$ day of observation.

\section{DISCUSSION}

C. mrigala spermatozoa cryopreserved with glucose at $0.5 \%$ concentration exhibited a motility duration which is $52 \%$ higher than that of Control and the value was statistically significant $(\mathrm{P}>0.025)$. All the samples cryopreserved with glucose at different concentrations had relatively higher percentage of post-thaw motility duration than that of Control (Table 1). As it is seen in fig.1, the rate of change in the motility duration for various doses of glucose in the cryopreserved $C$. mrigala spermatozoa did not show decline. There was distinct change in motility pattern.

The present results fall in line with the reports by other authors. Carolsfeld et al. (2003) stated that the post-thaw motility rate was $80-100 \%$ when piracanjuba (Brycon orbignyanus) sperm was cryopreserved with glucose at $5 \%$. Nascimento et al. (2010) reported the greatest post -thaw sperm motility of $81 \%$ with fastest sperm velocities when sperm samples of Amazonian freshwater fish

Table 3. Motility pattern observed at regular intervals in C. mrigala spermatozoa cryopreserved with glucose at different concentrations.

\begin{tabular}{lccccccc}
\hline Treatment & \multicolumn{7}{c}{ Days of cryopreservation } \\
\cline { 2 - 7 } & Initial & $\mathbf{7}$ & $\mathbf{1 4}$ & $\mathbf{2 1}$ & $\mathbf{2 8}$ & $\mathbf{3 5}$ & $\mathbf{4 2}$ \\
\hline Control & +++ & +++ & +++ & +++ & ++ & ++ & + \\
Glucose $0.25 \%$ & +++ & +++ & +++ & +++ & +++ & +++ & +++ \\
Glucose $0.5 \%$ & +++ & +++ & +++ & +++ & +++ & +++ & +++ \\
Glucose $0.75 \%$ & +++ & +++ & +++ & +++ & +++ & ++ & + \\
Glucose $1 \%$ & +++ & +++ & ++ & ++ & ++ & + & + \\
\hline
\end{tabular}




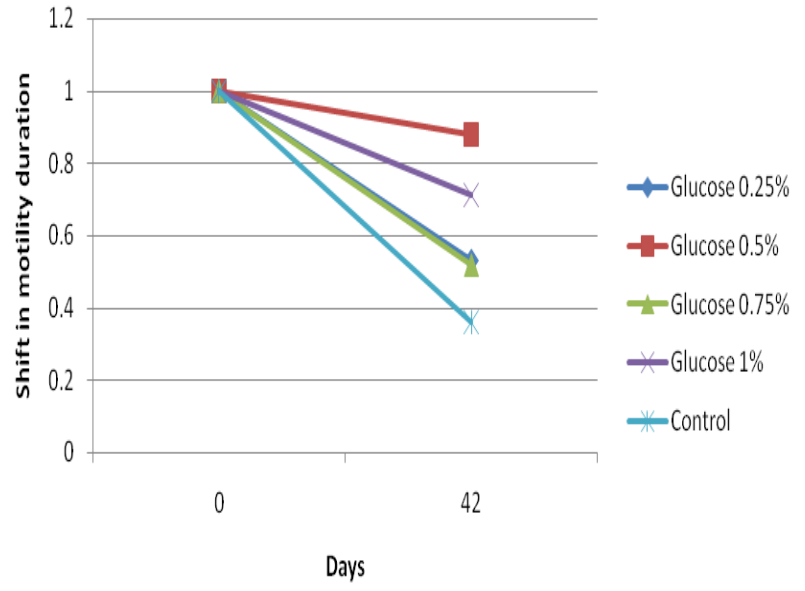

Fig. 1. Rate of change in motility duration of C. mrigala spermatozoa diluted and cryopreserved with glucose at different concentrations.

pirapitinga (Piaractus brachypomus) were cryopreserved in glucose-methylglycol. Similar result was observed by Viveiros et al. (2010) who cryopreserved the spermatozoa of Streaked prochilod (Prochilodus lineatus) in glucose and found $75 \%$ post-thaw motility. Martinez et al. (2012) also observed $71 \%$ post-thaw motility when glucose was used at $5 \%$ concentration during cryopreservation of bocachico (Prochilodus magdalenae).

The observations exhibited in the fig. 1 explain the swing in the motility pattern and duration that has been considered inherent and unavoidable in the cryopreservation of the gametes (Hammerstedt et al., 1990; Ohta et al., 1995; Chao and Liao, 2001). The increased concentration of glucose might have shifted the osmolality of the diluent thereby the motility duration was affected as commented by Hammerstedt et al. (1990) and Takai and Morisawa (1995).

The motility score of the cryopreserved spermatozoa showed similar reduction (Table 2). All the treatments including Control exhibited a sharp reduction in the motility score only after $14^{\text {th }}$ day. While it came down to 1 on $42^{\text {nd }}$ day for the Control, the samples contained glucose at different concentrations remained at 2 on $42^{\text {nd }}$ day. The change in the motility score was in accordance with the results obtained by Doi (1982). The observations on the motility pattern also indicated that the spermatozoa cryopreserved with glucose at $0.25 \%$ and $0.5 \%$ had been uniform without any alteration excepting on the number of cells.

These observations on motility score and motility pattern lead to the point that when energy supplements are provided, the efficiency of the spermatozoa could be protected in spite of a reduction in the number of motile cells. The motility pattern of the live spermatozoa after cryopreservation had a motility pattern that was useful for the fertilization of the eggs.

Le Roux and Steyn (1968) opined that high percentage of live sperm cells is a prerequisite to fertilize thousands of eggs deposited on a substrate during spawning activities in fishes. In the present study, the percentage of live cells was $71 \%$ when the spermatozoa were cryopreserved with glucose at $0.25 \%$ and $0.5 \%$ concentrations. The result was similar to Kruger et al. (1984) who found that the mean percentage of live sperm was in the range of $80-97 \%$ in C. carpio and Mohanraj (2009) who reported the mean percentage of live sperm in $C$. carpio to be $88 \%$. It is evident that glucose at concentrations of $0.5 \%$ alone can be used in the extender for enhancing the motility duration of the spermatozoa of $C$. mrigala.

\section{Conclusion}

In the present study, the motility duration of spermatozoa cryopreserved with glucose at $0.5 \%$ concentration showed the highest motility duration of $204 \pm 3.6 \mathrm{~s}$. Higher percentage of live cells (71\%) and forward movement of spermatozoa were observed when $0.5 \%$ glucose was supplemented during cryopreservation. Similar results on motility pattern and motility score were noticed when glucose was used at $0.25 \%$ concentration
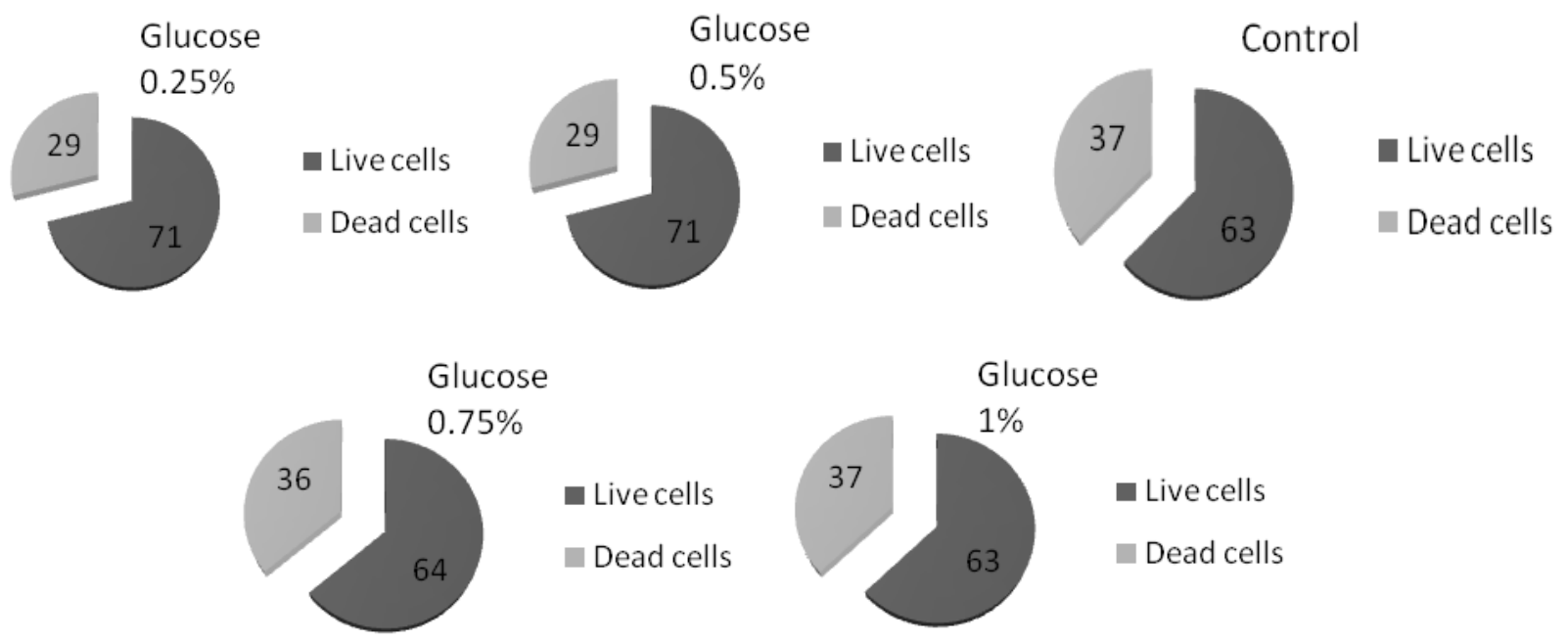

Fig. 2. Percentage of live and dead cells of C. mrigala milt cryopreserved with glucose at different concentrations. 
also. Hence it can be concluded that energy can be spared from external energy supplements like glucose (at $0.5 \% \mathrm{w} / \mathrm{v}$ ) for the spermatozoa activities.

This study would be beneficial for enhancing or protecting the efficiency of the spermatozoa subjected to the cryopreservation.

\section{ACKNOWLEDGEMENTS}

Tamil Nadu Veterinary and Animal Sciences University is greatly acknowledged for providing funding support to carry out the research work in the Institute.

\section{REFERENCES}

Akcay, E. and Bozkurt, S. (2004). Cryopreservation of mirror carp sperm. Turkion J. Veter. Ani. Sci., 28: 837-843.

Babiak, I., Glogowski, J., Luezynski, M.J., Kucharezyk, D. and Luezynski, M. (1995). Cryopreservation of the milt of the northern pike. J. Fish Biol., 46 (5): 819-828.

Betsy, C.J. (2013). Role of supplemented energy sources on spermatological parameters of selected cultivable carps. M.F. Sc. Thesis, pp 101.

Billard, R., Cosson, J., Perchec, G. and Linhart, O. (1995). Biology of sperm and artificial reproduction in carp. Aquaculture, 124: 95-112.

Blaxter, P.C. (1953). Sperm storage and cross fertilization of spring and autumn spawning herring. Nature, 172: 1189 -1190 .

Bozkurt, Y., Secer, S., Tekin, N., Akcay, E. (2005). Cryopreservation of Rainbow Trout (Oncorhynchus mykiss) and Mirror Carp (Cyprinus carpio) Sperm with Glucose Based Extender. Cilt I Sayn I, 21-25.

Carolsfeld, J., Godinho, H.P., Filho, E.Z. and Harvey, B.J. (2003). Cryopreservation of sperm in Brazilian migratory fish conservation. J. Fish Biol., 63: 472-489.

Chao, N.H. and Liao, I.C. (2001).Cryopreservation on finfish and shellfish gametes and embryos. Aquaculture, 197: 161-189.

Chao, N.H., Chan, W.C., Liu, K.C. and Liao, I.C. (1987). The properties of Tilapia sperm and its cryopreservation. $J$. Fish Biol., 30: 107-119.

Christen, F., Gatti, J.L. and Billard, R. (1987). Trout sperm motility- the transient movement of trout sperm is related to changes in the concentration of ATP following the activation of flagellar movement. Eur. J. Biochem., 166: 667-671.

Chutia, I.P., Krishna, G., and Chaudhary, A. (1998). Biochemical and biometrical analysis of carp milt. Fish genetics and Biodiversity conservation, Nature conservators, Muzaffarnager, pp 205-213.

Cruz-Casallas, P.E., Pardo-Carrasco, S.C., Arias-Castellanos, J.A., Lombo-Castellanos, P.E., Lombo-Rodríguez, D.A. and Pardo-Mariño, J.E. (2004). Cryopreservation of yamú Brycon siebenthalae milt. J World Aquacult Soc., 35:529-35.

Doi, M., Hoshino, T., Taki, Y. and Ogasawara, Y. (1982). Activity of the sperm of the Bluefin tuna Thunnus thynnus under fresh and preserved conditions. Bull. Japan Soc. Sci. Fish., 48(4): 495-498.

Dong, Q., Huang, C. and Tiersch, T.R. (2006). Post-thaw amendment of cryopreserved sperm for use in artificial insemination of a viviparous fish, the green swordtail Xiphophorus helleri. Aquaculture, 259: 403-414.
FAO (2014). Fishery and Aquaculture Statistics. Food and Agriculture Organization of the United Nations, Rome, 2014.

Fribourgh, B.H. (1966). The application of differential staining method to low temperature studies on goldfish spermatozoa. Prog. Fish Cult., 28: 227-231.

Gardiner, D.M. (1978). Utilization of extracellular glucose by spermatozoa of two viviparous fishes. Comparative Biochemistry and Physiology, 59: 165-168.

Glogowski, J., Ciereszko, R. and Dabrowski, K. (1999). Cryopreservation of Muskellunge and Yellow Perch semen. North American J. Aquaculture, 61: 258-262.

Grace, L.B. (2013). Deep freezing trials of Arius arius spermatozoa. $J$. Appl. Environ. Biol. Sci., 3(6): 42-47.

Guest, W.C., Avault, Jr.J.W. and Roussed, J.D. (1976). Preservation of channel catfish sperm. Trans. Am. Fish. Soc., 105: 469-474.

Hammerstedt, R.H., Graham, J.K. and Nolan, J.P. (1990). Cryopreservation of mammalian sperm: What we ask them to survive. Andrology, 11(3): 73-88.

Hamner, E and Charles, O.A. (1969). Physiological considerations in capacitatum of spermatozoa. In endocrinological de la reproduction. Mexico, D.E. La Prensa Medica Mexican, pp. 24-46.

Harvey, B. and Kelley, R.N. (1984). Chilled storage of Sarotheroden mossambicus milt. Aquaculture, 36: 85-95.

Henderson, N.E. and Dewar, J.E. (1959). Short term storage of brook trout milt. Prog. Fish. Cult., 21: 169-171.

Horváth, A., Miskolczi, E., Urbányi, B. (2003). Cryopreservation of common carp sperm. Aquat Living Resour., 16:457-460.

Kruger, J.C.D.W., Smit, G.L., Vuren, J.H.J.V. and Ferreiera, J.T. (1984). Some chemical and physical properties of the semen of Cyprinus carpio L. and Oreochromis mossambicus (Peters). J. Fish Biol., 24: 263-272.

Kurokura, H., Hirano, R., Tomita, M. and Iwahashi, M. (1984). Cryopreservation of carp sperm. Aquaculture, 37: 267-273.

Lahnsteiner, F. and Patzner, R.A. (1998). Sperm motility of the marine teleosts Boops boops, Diploduss argus, Mullus barbatus and Trachurus mediterraneus. J. Fish Biol., 52 (4):726-742.

Le Roux, P. and Steyn, L.(1968). In Visse van Transvaal. Kaapstad: Kaapen Transval Drukkers Beperk, pp. 29-30

Leung, L.K.P. and Jamieson, B.G.M. (1991). Live preservation of fish gametes. Fish evaluation and systematic evidence from spermatozoa. University Press, Cambridge, pp 245.

Lubzens, E., Daube, N., Pekarsy, I., Magnus, Y., Cohen, A.,Yusefovich, F. and Feigin, P. (1997). Carp (Cyprinus carpio L) spermatozoa cryobanks- strategies in research and application. Aquaculture, 155: 13-30.

Martínez, J.G., Tarazona-Morales, A.M. and Pardo-Carrasco, S.C. (2012). Sperm cryopreservation of freshwater fish bocachico (Prochilodus magdalenae) in DMSO and glucose and its effects on fertilization and hatching efficiency. Anim. Reprod., 9(1): 19-26.

Melo, F.C.S.A. and Godinho, H.P. (2006). A protocol for cryopreservation of spermatozoa of the fish Brycon orthotaenia. Animal Reproduction, 3(3): 380-385.

Mohanraj, P. (2009). Effect of cryopreservation on the irradiated spermatozoa of Cyprinus carpio (Linn.). M.F. Sc. Thesis, pp 71.

Mounib, M.S. (1967). Metabolism of pyruvate, acetate and glyoxylate by fish sperm. Comparative Biochemistry and Physiology, 20: 987-992.

Nascimento, A.F., Maria, A.N., Pessoa, N.O., Carvalho, 
M.A. and Viveiros, A.T. (2010). Out-of-season sperm cryopreserved in different media of the Amazonian freshwater fish pirapitinga (Piaractus brachypomus). Anim. Rep. Sci., 118 (2-4): 324-9.

Nomura, M. (1964). Studies on reproduction of rainbow trout Salmo gairdneri with special reference to egg takens VI- the activities of spermatozoa in different diluents and preservation of senmen. Bull. Japan Soc. Sci. Fish., 30: 723-733.

Ohta, H., Shimma, H. and Hirose, K. (1995). Relationship between fertility and motility of cryopreserved spermatozoa of the amago salmon Oncorhynchus masou ishikawae. Fisheries Science, 61(5): 886-887.

Perchec, G., Jeulin, C., Cosson, J., Andre, F. and Billard, R. (1995). Relationship between sperm ATP content and motility of carp spermatozoa. J. Cell. Sci., 108: 747-753.

Ponniah, A.G., Lakra, W.S. and Ogale, S.N. (1999). Effects of cryoprotectant and fertilization protocol on viability of Mahseer Tor khudree cryopreserved spermatozoa. $J$. Aqua Trop., 14(2): 153-158.

Purdy, P.H. (2006). A review on goat sperm cryopreservation. Small Rumin Res, 63:215-225.

Sarder, M.R.I., Rafiquzzaman, S.M., Sultana, R., and Faridul
Islam, M. (2009). Cryopreservation of spermatozoa of mrigal, Cirrhinus cirrhosus with a view to minimize inbreeding and hybridization. J. Bangladesh Agri. Univ., 7(1): 211-215.

Stein, H. (1975). Spezielleuntersuchungen am Fischspermaunterbesonderer Berucksichtigung der spermakonservierung. Dissertation, Tech UniverststMunchen.

Stoss, J. and Refstie, T. (1983). Short-term storage and cryopreservation of milt from Atlantic salmon and Sea Trout. Aquaculture, 30: $229-236$

Takai, H. and Morisawa, M. (1995). Changes in intracellular $\mathrm{K}^{+}$concentration caused by external osmolality change regulate sperm motility of marine and freshwater teleosts. J. Cell. Sci., 108: 1175-1181.

Viveiros, A.T.M., Godinho, H.P. (2009). Sperm quality and cryopreservation of Brazilian freshwater fish species: a review. Fish Physiol Biochem., 35:137-150.

Viveiros, A.T., Nascimento, A.F., Orfão, L.H. and Isaú, Z.A (2010). Motility and fertility of the subtropical freshwater fish streaked prochilod (Prochilodus lineatus) sperm cryopreserved in powdered coconut water. Theriogenology, 74(4): 551-556. 